\title{
Technology Transfer and Commercialization Annual Report 2008
}

December 2008

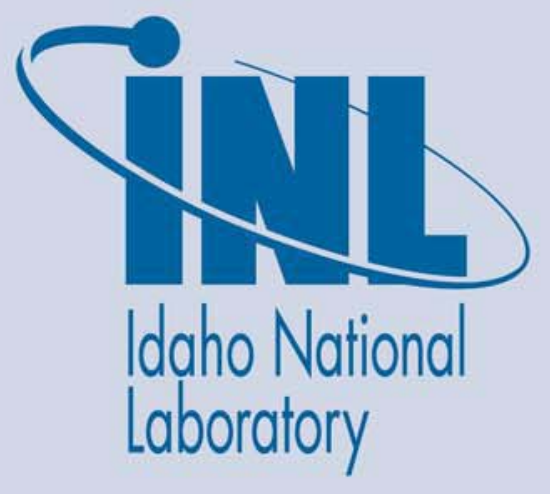

The INL is a U.S. Department of Energy National Laboratory operated by Battelle Energy Alliance 
INL/EXT-08-15149

\title{
Technology Transfer and Commercialization Annual Report 2008
}

December 2008

\author{
Idaho National Laboratory \\ Technology Transfer \& Commercialization \\ Idaho Falls, Idaho 83415
}

http://www.inl.gov

Prepared for the

U.S. Department of Energy

Office of Science

Under DOE Idaho Operations Office

Contract DE-AC07-05ID14517 


\section{DISCLAIMER}

This information was prepared as an account of work sponsored by an agency of the U.S. Government. Neither the U.S. Government nor any agency thereof, nor any of their employees, makes any warranty, expressed or implied, or assumes any legal liability or responsibility for the accuracy, completeness, or usefulness, of any information, apparatus, product, or process disclosed, or represents that its use would not infringe privately owned rights. References herein to any specific commercial product, process, or service by trade name, trade mark, manufacturer, or otherwise, does not necessarily constitute or imply its endorsement, recommendation, or favoring by the U.S. Government or any agency thereof. The views and opinions of authors expressed herein do not necessarily state or reflect those of the U.S. Government or any agency thereof. 



\begin{abstract}
This report is a catalog of selected Idaho National Laboratory technology transfer and commercialization transactions during fiscal year 2008. The size and diversity of INL technical resources, coupled with the large number of relationships with other organizations, virtually ensures that a report of this nature will fail to capture all interactions. Recognizing this limitation, this report focuses on transactions that are specifically authorized by technology transfer legislation (and corresponding contractual provisions) or involve the transfer of legal rights to technology to other parties.

This report was compiled from primary records, which were readily available to the INL's Office of Technology Transfer \& Commercialization. However, the accomplishments cataloged in the report reflect the achievements and creativity of the researchers, technicians, support staff, and operators of the INL workforce.
\end{abstract}




\section{CONTENTS}

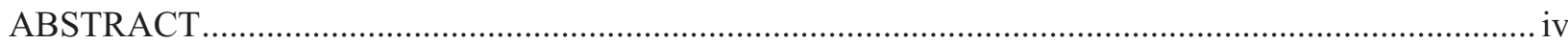

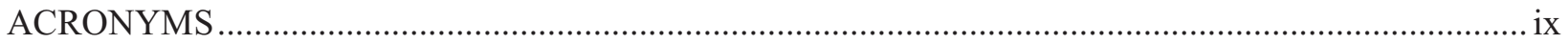

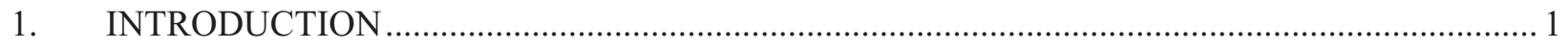

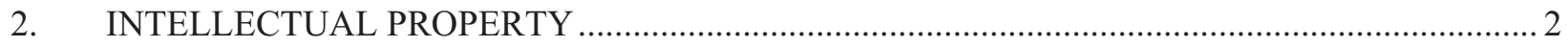

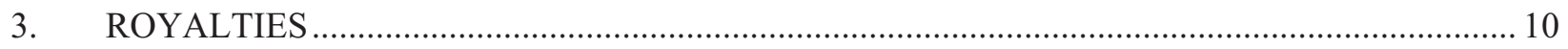

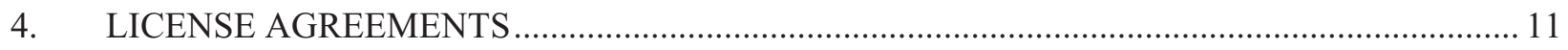

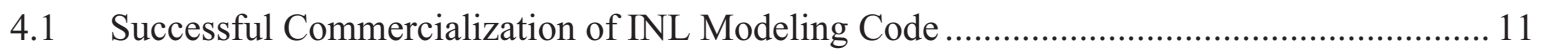

4.2 INL Licenses Xtreme Xylanase to Xtreme Biochemicals ................................................. 12

4.3 INL Licenses Power-Generating Batteries to M2E........................................................... 12

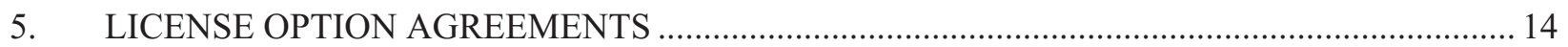

5.1 INL Signs Multi-Million Dollar License Option Agreement and CRADA with

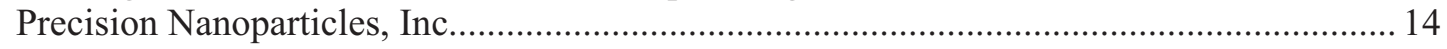

5.2 INL Signs License Option Agreement with Northstar Medical Radioisotopes, LLC............ 14

6. COOPERATIVE RESEARCH AND DEVELOPMENT AGREEMENTS .................................... 15

6.1 INL Partners With Oshkosh Defense to Develop Next-Generation Vehicle Armor............. 15

6.2 INL Signs Multi-Million Dollar CRADA with Battelle Memorial Institute and Other

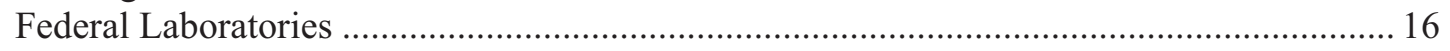

6.3 INL Signs Multi-Million Dollar CRADA with BKS Energy, LLC ...................................... 16

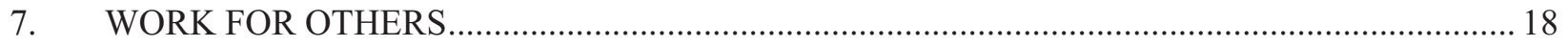

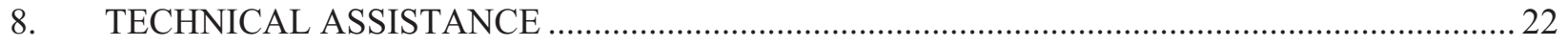

8.1 Unique Glasswork Contributes to INL and Community ................................................... 22

8.2 INL Assists Community Efforts to Preventing Domestic Violence...................................... 23

8.3 Preserving History: One Roof at a Time ....................................................................... 23

9. INL ECONOMIC DEVELOPMENT 2008 PROGRAM HIGHLIGHTS ......................................25

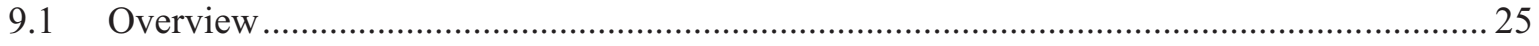

9.2 Economic Development Asset Enhancement .................................................................. 25

9.3 INL continues to work with the Eastern Idaho Entrepreneurial Center .............................. 25

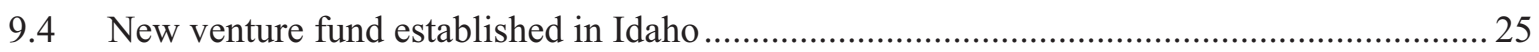

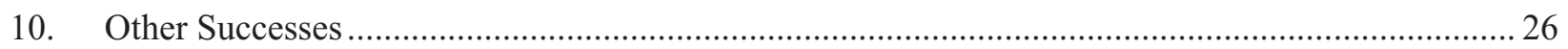

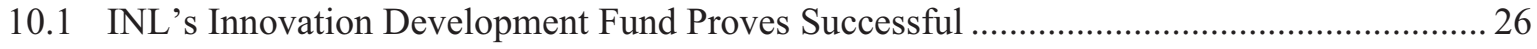

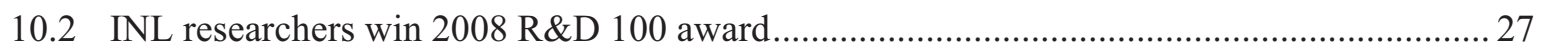

10.3 INL Recognized with Three FLC Far West Region Awards ............................................. 27

10.4 Laboratory Technologies Recognized at Annual Event.................................................. 27 


\section{ACRONYMS}

AMI/AMR Advanced Meter Infrastructure/Advanced Meter Reading

ARC Alberta Research Council

BEA Battelle Energy Alliance

BRE Business Retention and Expansion

BYU-ID Brigham Young University-Idaho

CIP Critical Infrastructure Protection

CMMAD Countermine Mobility, Marking, Autonomy \& Detection

CRADA Cooperative Research and Development Agreement

DARPA Defense Advanced Research Project Agency

DOE Department of Energy

DTRA Defense Threat Reduction Agency

DVIC Domestic Violence Intervention Center

EBR-II Experimental Breeder Reactor-II

EFP explosively formed penetrator

EPA U.S. Environmental Protection Agency

GEOPS Geologic and Environmental Probe System

IED improvised explosive device

IEDA Idaho Economic Development Association

IEDS Idaho Explosives Detection System

INL Idaho National Laboratory

IP Intellectual Property

IRP Idaho Rural Partnership

ISU Idaho State University

ITC Idaho TechConnect

JAEA Japanese Atomic Energy Agency

JCTD Joint Concept Technology Demonstration

KEPRI Korea Atomic Energy Research Institute

LNG liquefied natural gas

NCS National Communications System

NERC North American Electric Reliability Corporation

NSSC Naval Sea Systems Command

NVESD Night Vision \& Electronic Sensors Directorate

OPR Offsite Recovery Program 
ORNL Oak Ridge National Laboratory

PFTT Privately Funded Tech Transfer

PII Performance Improvement International

PNNL Pacific Northwest National Laboratory

PNWER Pacific Northwest Economic Region

R\&D research and development

RIDM Risk Informed Decision Making

SAPHIRE Systems Analysis Program for Hands-on Integrated Reliability Evaluation

SIEDO Southern Idaho Economic Development Organization

SRNL Savannah River National Laboratory

STIRS Smart Threads Integrated Radiation Sensor

TEMA Toyota Motor Engineering \& Manufacturing North America Inc.

TNT trinitrotoluene

TSA Technical Services Agreement

$\mathrm{U}$ of I University of Idaho

UAMPS Utah Associated Municipal Power Systems

USAID United States Agency for International Development

WBC Wyoming Business Council

WCS Waste Control Specialists

WFO Work for Others

WPS Work for Others Automated Processing System 


\section{Technology Transfer and Commercialization Annual Report 2008}

\section{INTRODUCTION}

Idaho National Laboratory (INL) is a Department of Energy (DOE) multi-program national laboratory that conducts research and development in all DOE mission areas. Like all other federal laboratories, INL has a statutory, technology transfer mission to make its capabilities and technologies available to all federal agencies, to state and local governments, and to universities and industry. To fulfill this mission, INL encourages its scientific, engineering, and technical staff to disclose new inventions and creations to ensure the resulting intellectual property is captured, protected, and made available to others who might benefit from it. As part of the mission, intellectual property is licensed to industrial partners for commercialization, creating jobs and delivering the benefits of federally funded technology to consumers. In other cases, unique capabilities are made available to other federal agencies or to regional small businesses to solve specific technical challenges. In other interactions, INL employees work cooperatively with researchers and other technical staff of our partners to further develop emerging technologies.

This report is a catalog of selected INL technology transfer and commercialization transactions during this past year. The size and diversity of INL technical resources, coupled with the large number of relationships with other organizations, virtually ensures that a report of this nature will fail to capture all interactions. Recognizing this limitation, this report focuses on transactions that are specifically authorized by technology transfer legislation (and corresponding contractual provisions) or involve the transfer of legal rights to technology to other parties.

This report was compiled from primary records, which were readily available to the INL's Office of Technology Transfer \& Commercialization. The accomplishments cataloged in the report, however, reflect the achievements and creativity of the highly skilled researchers, technicians, support staff, and operators of INL's workforce. Their achievements and recognized capabilities are what make the accomplishments cataloged here possible. Without them, none of these transactions would occur. 


\section{INTELLECTUAL PROPERTY}

Intellectual Property (IP) in the form of copyrights and patents provides the foundation for interactions between national laboratories and other parties. The intellectual property estate of an R\&D organization also serves as a measure of the institution's ability to do creative, meaningful research.

Technology Transfer \& Commercialization works closely with INL programs to identify and pursue technology commercialization and business development opportunities. In 2008, 83 invention disclosures were submitted to Battelle Energy Alliance (BEA) by INL inventors and 38 U.S. patents were issued either to INL or DOE based on the inventions of INL scientists and researchers.

BEA has the right under its contract, subject to some exceptions, to take title to inventions and seek patent protection. The decision of whether or not to take title and seek patent protection is based on market and technical assessments of the technology and its subsequent programmatic value. Market assessments are performed and a recommendation is presented to a committee comprised of department or project managers, assistant lab director or designee, market analysts, commercialization managers, and patent attorneys. These recommendations are presented before the team, where a final decision is made to elect or decline the technology for patent protection. Generally, if the invention is judged as commercially valuable, crucial to a primary mission, or valuable in terms of motivating further research funding, it is elected. If BEA decides to decline title, DOE decides on whether to seek patent protection in its own name. If DOE decides not to seek patent protection, the inventor(s) may petition to have title waived to them by DOE with the expectation that they will pursue patent protection using their own resources.

A brief description of each patent issued during FY 2008 based on INL inventions is provided on the following pages.

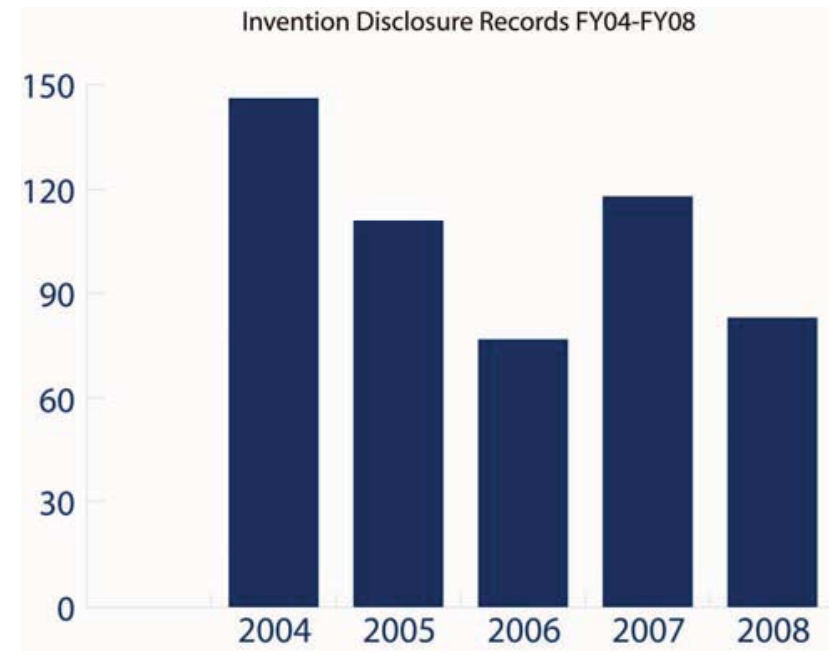

U.S. Patents Issued FY04-FY08

80

70

60

50

40

30

20

10

0
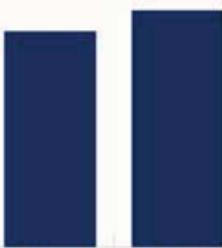

2005

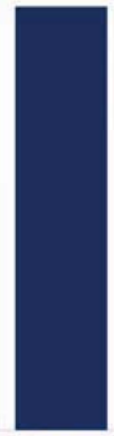

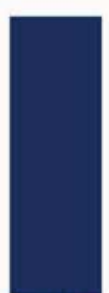

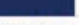

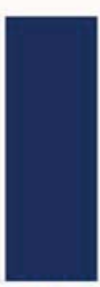

2008 


\section{Methods for Coating Conduit Interior Surfaces Utilizing a Thermal Spray Gun with Extension Arm}

Karen Moore is being recognized for the innovative approach of lining interior surfaces of an instrument with a spray gun. Such an approach may allow for an increase in strength and durability while at the same time reduce frictional loss.

Patent Number: 7,276,264 Date Issued: 2 October 2007

\section{A Method of Forming a Chemical Composition}

As hydrogen-powered vehicles become a reality, there becomes a need for addressing how to store and dispense hydrogen as a fuel. Inventors Bruce Wilding, Dennis Bingham, Kerry Klingler, and Thor Zollinger have developed a low cost method of recycling borate into borohydride.

Patent Number: 7,279,077 Date Issued: 9 October 2007

\section{Method of Installing Subsurface Barrier}

John Richardson, Kevin Kostelnik, Paul Sloan, and Reva Nickelson have developed a technology for insitu installation of a sub-surface containment system enclosing an existing waste volume. The resulting structure can be both inspected and monitored over time to verify performance and the physical topology allows in-situ repair if necessary.

Patent Number: 7,278,800 Date Issued: 9 October 2007

\section{Systems for Low Frequency Seismic and Infrasound Detection of Geo-pressure Transition Zones}

In the drilling of petroleum and other deep wells, one of the difficulties is in detecting when a drilling operation may be approaching or entering zones of increasing pressure. Michael Shook has developed a method for seismic exploration and detection of a pressurized zone within a subterranean formation.

Patent Number: 7,283,422 Date Issued: 16 October 2007

\section{Methods for Measurement of a Dimensional Characteristic and Methods of Predictive Modeling Related Thereto}

Eric Robertson, in collaboration with Richard Christiansen, a Colorado School of Mines professor, pursued a new approach that significantly reduces the time required to obtain swelling properties of coal. The benefits of such an approach include more accurate modeling of $\mathrm{CO}_{2}$ sequestration in coal beds and increased energy production from coals.

Patent Number: 7,284,604 Date Issued: 23 October 2007 


\section{Neutron Absorbing Coating for Nuclear Criticality Control}

The nuclear power industry and the U.S. Department of Energy need to store spent nuclear fuel at a geologic repository. The proposed site for this long term repository is at Yucca Mountain, Nevada. The storage containers for the spent nuclear fuel require corrosion resistant, neutron absorbing materials to prevent nuclear criticality in the event of a waste package breach and water ingress. Ronald Mizia, Richard Wright, David Swank, Tedd Lister, and Patrick Pinhero are credited for a new, neutron absorbing material in powder form which may be applied to storage container fuel basket internals by a thermal spray process.

Patent Number: 7,286,626 Date Issued: 23 October 2007

\section{Safe Battery Solvents}

Through a team effort, Mason Harrup, Frederick Stewart, and Thomas Luther have developed a safer electrolyte for lithium batteries that maintains a very low vapor pressure, is flame retardant, and is nontoxic.

Patent Number: 7,285,362 Date Issued: 23 October 2007

\section{Method, Apparatus, and System for Controlling Fluid Flow}

Daniel Ginosar has developed a new product to be used in the control valve market. This system will provide the resolution necessary to precisely control compressible fluid flow in the presence of a large pressure drop and can be used for such things as pharmaceutical development and manufacturing and petroleum and alternative fuels development.

Patent Number: 7,287,541 Date Issued: 30 October 2007

\section{Cesium and Strontium Extraction Using a Mixed Extractant Solvent Including Crown Ether and Calixarene Extractions}

Cesium-137, strontium-90, and actinides account for a significant amount of the radioactivity of liquid wastes, such as high level liquid wastes from nuclear fuel reprocessing. INL researchers David Meikrantz, Terry Todd, Catherine Riddle, Jack Law, Dean Peterman, Bruce Mincher, Christopher McGrath, and John Baker have developed a system that simultaneously removes or extracts cesium and strontium from an acidic solution, thus reducing the need to create new storage facilities.

Patent Number: 7,291,316 Date Issued: 6 November 2007

\section{Method for Producing a Chemical Hydride}

Bruce Wilding, Dennis Bingham, Kerry Klingler, Kraig Wendt, and Thor Zollinger collaborated on developing a process that recycles sodium borate into sodium borohydride. Such a process will allow for a safer source of transporting hydrogen, as well as the capability to deliver at least eight times the amount of hydrogen over conventional processes.

Patent Number: 7,294,323 Date Issued: 13 November 2007 


\section{A Method and Apparatus for Chemical Synthesis}

Inventors Peter Kong, Jon Grandy, and Stephen Herring are credited for developing a method of converting sodium borate to sodium borohydride. Sodium borohydride is a safe source for storing and transporting hydrogen and can be used as a precursor material to boron-based fuels for hydrogen-powered vehicles, stored hydrogen gas for industrial processes, and distributed power applications.

Patent Number: 7,303,657 Date Issued: 4 December 2007

\section{Infrared Tag and Track Technique}

James Davidson, John Slater, Judy Partin, and Mark Stone were named on a patent that addresses a technique of tagging and tracking covert objects and may be detected using a portable camera system. This technique may help government agencies and industrial firms catch smugglers or prevent export of export-controlled components.

Patent Number: 7,304,300 Date Issued: 4 December 2007

\section{Explosives Detection System and Method}

Andrew Edwards, Edward Seabury, Edward Reber, James Jewell, Kenneth Rohde, Kurt Derr, and Larry Blackwood have developed an explosive detection system that detects bombs in vehicles. The benefit of this new system will provide operators the ability to detect smaller quantities in a shorter amount of time.

Patent Number: 7,307,256 Date Issued: 11 December 2007

\section{Polybenzimidazole Compounds, Polymeric Media, and Methods of Post-Polymertization Modifications}

Due to the team effort of John Klaehn, Eric Peterson, Christopher Orme, Michael Jones, Alan

Wertsching, Thomas Luther, and Tammy Trowbridge, a better way of handling and processing a polymer has now been developed that at one time could only be handled in very heavy, low vapor pressure organic solvents. With this new process, the material is modified to provide increased solubility in higher vapor pressure solvents and at significantly greater concentrations.

Patent Number: 7,309,758 Date Issued: 18 December 2007

\section{Apparatuses for Interaction with a Subterranean Formation, and Methods of Use Thereof}

Don Clark, Richard Jones, Terry Turner, Joel Hubbell, and James Sisson developed the Geologic and Environmental Probe System (GEOPS) for monitoring and sampling pore fluids in geologic sediments using the sonic and direct push-drilling techniques. GEOPS won a R\&D 100 award in 2004 for providing a technique to safely sample and monitor below contaminated materials. GEOPS was successfully used at the INL's Subsurface Disposal Area to characterize the buried waste.

Patent Number: 7,311,011 Date Issued: 25 December 2007

\section{Complex Pendulum System Biomass Sensor}

Ben Perrenoud, Kevin Kenney, and Reed Hoskinson have developed a control system that measures biomass entering a combine both quantitatively and qualitatively. This system will benefit the ongoing development and enhancement of an autonomous control system for a grain combine.

Patent Number: 7,311,013 Date Issued: 25 December 2007 


\section{Ion Exchange Materials, Method of Forming Ion Exchange Materials, and Methods of Treating Liquids}

Alan Wertsching, Eric Peterson, and John Wey are credited for inventing a system that exceeds the conditions typically found in commercial water softeners today. This new system withstands elevated temperatures and pressures and is a more robust form of water softener than is found in current methods.

Patent Number: 7,312,175 Date Issued: 25 December 2007

\section{Method for Forming a Hardened Surface on a Substrate}

Now working for the INL spinout, The NanoSteel Company, Daniel Branagan was named sole inventor on an innovative method of forming a metallic coating over a metallic substrate. This technology can be used for a new class of steel that significantly increases the hardness and strength over conventional steel alloys.

Patent Number: 7,323,071 Date Issued: 29 January 2008

\section{Methods and System for Pipeline Communication}

Both real-time status monitoring and secure communications are needs of the pipeline industry to ensure infrastructure security and maximal use of existing capacity. To help solve this need, John Richardson has developed a technology that uses thick film resistance lines spayed onto a transmission media.

Furthermore, it allows remote and automatic monitoring of remote sensors or transmission of supervisory control information within a natural gas transmission pipeline or similar linear structure.

Patent Number: 7,324,011 Date Issued: 29 January 2008

\section{Spectral Analysis Method for Detecting an Element}

In collaboration with the United States Air Force Electronics Systems Center, INL engineers Andrew Edwards, Edward Seabury, Edward Reber, James Jewell, and Larry Blackwood have perfected and deployed a portal-style vehicle-borne detection unit known as the Idaho Explosives Detection System (IEDS). In 2006, IEDS was installed at Ohio's Wright-Patterson Air Force Base for random anti-terrorism field testing.

Patent Number: 7,329,872 Date Issued: 12 February 2008

\section{System, Method and Computer-readable Medium for Locating Physical Phenomena}

John Richardson, David Rohrbaugh, and Matthew Weseman are credited for developing a method based on ratios of certain prime numbers for encoding data by employing the use of resistive traces applied onto the surface of a transmission media. Furthermore, this new process allows remote and automatic detection, identification, and quantification of strain in a gas pipeline or similar linear structure.

Patent Number: 7,334,485 Date Issued: 26 February 2008 


\section{Frame for a Firearm}

David Crandall and Richard Watson are credited for the development of a firearm frame supporting a barrel, a receiver, and a firing mechanism; wherein the barrel and receiver form a moveable assembly and the firing mechanism is stationary. This firearm frame also includes an elongated support structure which was adapted to directly support the moveable assembly.

Patent Number: 7,337,574 Date Issued: 4 March 2008

\section{Metallic Coatings on Silicon Substrates, and Methods of Forming Metallic Coatings on Silicon Substrates}

Through a collaborative effort, Daniel Branagan, James Fincke, and Timothy Hyde have developed a method of coating silicon materials with steel and metalizing silicon surfaces.

Patent Number: 7,341,765 Date Issued: 11 March 2008

\section{Method for Making an Energetic Material}

Sole inventor Robert Fox received a patent for developing a method for making trinitrotoluene (TNT) in supercritical fluid carbon dioxide using nitric acid, toluene, and an organophosphorus surfactant. Dehydration of nitric acid and the formation of the nitronium ion nitrating agent is accomplished in the supercritical fluid carbon dioxide solvent by the combined affects of the organophosphorus agent and the supercritical fluid. This method produces TNT in the absence of sulfuric acid, greatly diminishes secondary acid waste solutions, and eliminates the formation of "Red Water."

Patent Number: 7,345,208 Date Issued: 18 March 2008

\section{Armor Structures}

Henry Chu and Jeffrey Lacy have developed an armor system that is designed to defeat very large-caliber breaching weapons, such as an explosive-driven flyer plate device typically used by terrorists to gain access to critical facilities and valuable materials.

Patent Number: 7,350,450 Date Issued: 1 April 2008

\section{A Chemical Reactor and Method for Chemically Converting a First Material into a Second Material}

Peter Kong is the sole inventor on the development of a chemical reactor and method for transforming a combustion flame into a highly reactive thermal plasma state for chemical hydrides and other materials synthesis.

Patent Number: 7,354,561 Date Issued: 8 April 2008

\section{Apparatus and Methods for Determining at Least One Characteristic of a Proximate Environment}

Michael Anderson, Phillip West, and Stephen Novascone teamed up to develop a mechanism that relates to a measurable behavior of a rotating mass-imbalance to the physical properties of a surrounding acoustic medium. The surrounding acoustic medium exerts an opposing torque on the rotating massimbalance that affects the operational frequency and amplitude of the device.

Patent Number: 7,357,030 Date Issued: 15 April 2008 


\section{Friction Stir Welding Tool}

Charles Tolle, Denis Clark, and Timothy Barnes were named on a patent that relates to a Friction Stir welding tool. This invention limits the exotic materials to key tool components, is easily replaceable and interchangeable, and can be adapted to the material being welded.

Patent Number: 7,357,292 Date Issued: 15 April 2008

\section{Method and Apparatus for Monitoring Characteristics of a Flow Path Having Solid Components Flowing Therethrough}

A patent credited to Gracy Elias, John Svoboda, Reed Hoskinson, and William Bauer accurately measures the amount of grain being lost by a grain combine as it is harvesting a crop. The grain could be any crop, such as wheat, barley, corn, soybeans, or rice. This invention will improve the productivity of the agricultural crop production and improve the energy-efficiency of agriculture.

Patent Number: 7,367,880 Date Issued: 6 May 2008

\section{High Capacity Adsorption Media for Separating or Removing Constituents and Methods of Producing and Using the Adsorption Media}

Nicholas Mann, Scott Herbst, Terry Todd, and Troy Tranter have developed a method of producing a novel composite resin to remove arsenic contamination from groundwater. The engineered composite bead has loading ratios of up to $85 \%$ metal oxide nanoparticles and $15 \%$ polymer, with surface area measurements exceeding $300 \mathrm{~m}^{2} / \mathrm{g}$. This material has been shown to exhibit a substantially higher capacity for arsenic than existing exchange materials.

Patent Number: 7,368,412 Date Issued: 6 May 2008

\section{Method for Oil Shale Pollutant Sorption/NOx Reburning Multi-pollutant Control}

Currently, an intense amount of research and development is underway in order to provide cost effective solutions to better control air pollutant emissions. Due to the efforts of Richard Boardman and Robert Carrington, a novel, simple, and economical method has been developed that uses ground oil shale to reduce air pollutant emissions during coal and waste feed combustion and gasification.

Patent Number: 7,384,615 Date Issued: 10 June 2008

\section{Induction Melter Apparatus}

Inventors Brian Raivo, Jay Roach, John Richardson, and Nicholas Soelberg have developed an innovative high frequency induction melter system for application to immobilization of high level radioactive waste. The intellectual property is focused on specific unique configurations for the glass draining and off-gas interface systems that offer significant improvement in material throughput and operations flexibility.

Patent Number: 7,388,896 Date Issued: 17 June 2008

\section{Optimally Moderated Nuclear Fission Reactor and Fuel Source Therefor}

Abderrafi Ougouag, Hans Gougar, and William Terry collaborated on the development of continuously refueling reactors, such as pebble-bed reactors. The two main advantages for continuous operation in an optimally moderated mode are its enhanced safety and economics.

Patent Number: 7,403,585 Date Issued: 22 July 2008 


\section{Polymeric Hydrogen Diffusion Barrier, High Pressure Storage Tank so Equipped, Method of Fabricating a Storage Tank and Method of Preventing Hydrogen Diffusion}

Sole inventor Paul Lessing is credited for his work on preventing slow leakage of hydrogen out of high pressure storage tanks. This invention features three layers of electrically active polymer materials that can be applied by dipping the inside of the tank.

Patent Number: 7,402,234 Date Issued: 22 July 2008

\section{Method for Reactivating Solid Catalysts and a Method for Recycling Supercritical Fluids Used to Reactivate the Catalysts}

Alkylation is an important refining process that produces alkylate, a high-octane, ultra-clean blending stock that comprises 13\% of today's gasoline. Daniel Ginosar, David Thompson, and Raymond Anderson are credited for developing a way to reactivate a catalyst that is contaminated with a fouling agent.

Patent Number: 7,407,905 Date Issued: 5 August 2008

\section{Method for Forming Ammonia}

Larry Zuck, Peter Kong, and Robert Pink collaborated on developing a method for forming ammonia which includes the steps of forming a plasma; providing a source of metal particles, and supplying the metal particles to the plasma to form metal nitride nanoparticles; and reacting the metal nitride particles with water to produce ammonia, and an oxide byproduct. The oxide byproduct is recycled back to the plasma reactor to regenerate the metal nitride nanoparticles.

Patent Number: 7,413,721 Date Issued: 19 August 2008

\section{Laser Device}

Jill Scott and Paul Tremblay were named on a patent for a laser device beam manipulation mechanism, which comprises a wavelength independent virtual source. The mechanical resolution is repeatable and two orders of magnitude finer than the spatial resolution of laser energy at the target position.

Patent Number: 7,414,241 Date Issued: 19 August 2008

\section{Method for Producing a Borohydride}

Peter Kong is credited for developing a method of synthesizing borohydrides in a single step.

Patent Number: 7,420,027 Date Issued: 2 September 2008 


\section{ROYALTIES}

The legislation that governs INL technology transfer activities authorizes the laboratory to retain and use funds generated through the licensing of technology. This licensing income can be used in a variety of ways to reward inventors and to further the technology transfer mission of the Laboratory.

Licensing income reached more than $\$ 1.2 \mathrm{M}$ during 2008. While the funds generated are very useful to the laboratory, funding significant rewards for inventors and important development work in the laboratory; their primary importance is as an indicator of the impact INL developed technologies are having in commercial markets. This economic

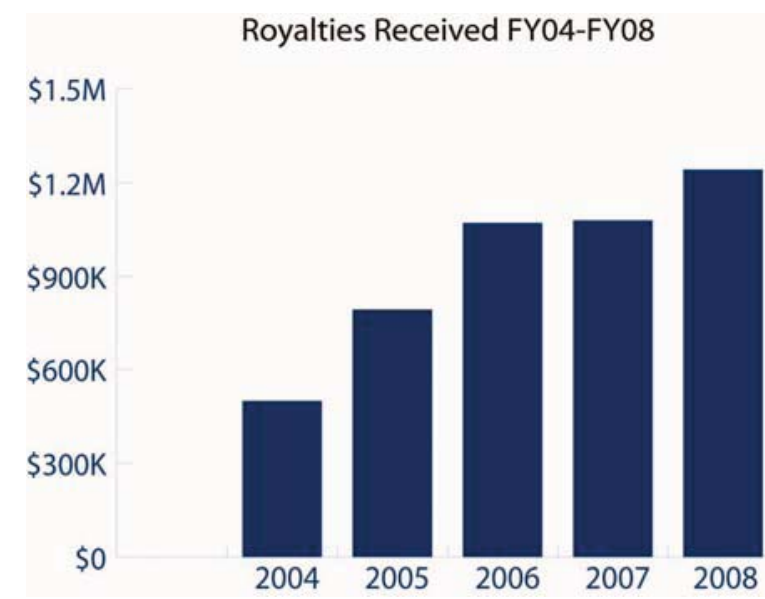
impact constitutes mission accomplishment in our technology transfer mission.

Royalties were used to assist researchers in various projects during FY 2008. For example, here are two particular development projects:

Gun barrels are constructed of steels that are susceptible to erosion and cracking due to an energetic ignition event that takes place every time a ballistic projectile, i.e., a bullet, is fired. Not only is there the expansive release of corrosive gases when the ignition cap is activated, but there is also the mechanical wear and tear associated with metal-on-metal contact between the projectile and the rifling surfaces in the interior of the barrel. Catastrophic failures associated with gun barrel erosion and cracking are rare due to vigilance on the part of owners and operators, but the costs associated with replacement due to loss of accuracy are staggering.

With assistance from the Lab's royalty share, the gun barrel enhancer was developed. This invention constitutes the creation of a unique barrel-life extension coating material and delivery system that applies both a lubricating film and a damage preventative to bore surfaces of ballistic weapons. Potential applications include any ballistic system, from small caliber guns to large artillery weapon systems.

Another development project that used Lab royalty was INL's Blue Mussel Adhesive. Small- and large-scale production runs of Mytilus edulis recombinant proteins (Mefp-1, Mefp-2, Mefp-3) were performed in order to assess the relative performance of the proteins individually and in combination. 


\section{LICENSE AGREEMENTS}

License agreements between BEA and a business (or other entity) allow the business to reproduce, manufacture, sell, or use INL-developed or owned intellectual property. INL contractor-owned inventions are available for licensing for commercialization by U.S. and foreign companies and organizations. The INL licenses its intellectual property on much the same terms as universities, other research organizations and industrial firms.

Selected licenses are featured below. A list of the remaining new licenses is found thereafter.

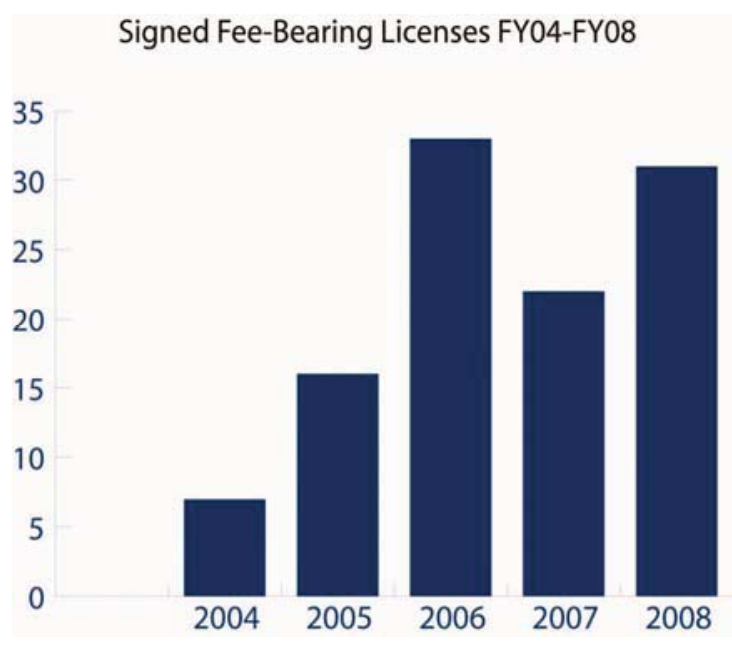

\subsection{Successful Commercialization of INL Modeling Code}

Wyoming Business Council (WBC) and INL's award-winning commercialization success story exemplifies how the commercialization of valuable modeling code can catalyze technology development.

Over the years, INL has amassed a library of computer simulated process models, such as IGCC plant models, synthetic liquid fuel plant models, and ammonia production process models, through government-funded projects. Each of these models has individual unit operations which can be moved around, hooked together, and modified to model new processes proposed by developers. INL's commercialization manger, Jason Stolworthy and Richard Boardman recognized the value of such assets once he realized that these models were distributed among researchers and not fully recognized as potentially valuable intellectual property. Stolworthy, along with Anastasia Gribik, Rick Wood, and Richard Boardman began cataloging, seeking copyright protection, and developing an intellectual property strategy for the IP. This asset later became the basis for the WyINL code.

During this time, INL sought partnership with WBC in hopes that they would be able to help in the development of the code, as well as look at it as a licensing opportunity. In the formative stages of the WBC and INL collaboration, both Boardman, lead researcher at INL, and Robert Jensen, CEO of WBC, recognized the need to make engineering expertise and modeling capabilities available to energy and chemical businesses who wish to locate in the State of Wyoming. INL and WBC therefore developed a plan to acquire, build, and maintain such expertise and modeling capabilities. The result was the commercialization of a generic set of process computer simulation models and a specific library of plant designs, hereinafter referred to as the "WyINL code."

After INL and WBC recognized the need to work together to make engineering expertise and modeling capabilities available to energy and chemical businesses, Boardman, Stolworthy, and Jensen put together a strategy to commercialize models through WBC. It was decided that WBC's primary role was to secure funding to help develop and maintain the WyINL code and interface with private industry.

In the short time span of six months, the relationship between INL and WBC has proven to be very successful. Thus far, Baard Energy, NERD Oil, and Gas and Energy Expediters have licensed the WyINL code for individual applications, resulting in licensing fees that will help further the commercialization efforts and provide more than half a million dollars for services. 
Because of this outstanding partnership, businesses are truly recognizing the value of the code. Especially businesses that are promoting new processes that solve unique challenges; one being the millions of dollars that are required to build a pilot plant or a full scale plant. Another challenge is that investors are reluctant to provide investment unless plant performance, emissions, costs, and other factors are validated. However, because the WyINL code significantly reduces the perceived risks, it makes it extremely valuable to businesses that are seeking large investments. For relatively little money, a business can model their process and provide simulated performance and cost estimates which provides investors additional confidence in the process.

The WyINL code is playing an instrumental role in the commercialization of each of these plants. It is a tool that has been commercialized through INL and WBC that enables and catalyzes the commercialization of other technologies. The "WyINL Code" is becoming a recognized and valued tool among the engineering community.

\subsection{INL Licenses Xtreme Xylanase to Xtreme Biochemicals}

Idaho National Laboratory (INL) and 13-D Research, Inc. (13-D), a long-term investment research firm, have developed a collaborative arrangement to co-develop "disruptive" energy technologies. This most unusual combination of a Department of Energy (DOE) national laboratory and investment research firm was the result of meeting the needs of two very different types of companies. As a national laboratory, INL is often faced with a need for funding to advance the development of a promising technology. In contrast, 13-D represents clients who are interested in investing in "step-changing" technologies. The collaboration between the entities began with an initial visit to INL where 13-D Research was exposed to a plethora of novel energy-related technologies and where David Anderson, commercialization manager with the Technology Transfer \& Commercialization Office, discussed the benefits and challenges of collaborating in developing and demonstrating technologies at a national laboratory. Over several months and additional face-to-face meetings, 13-D concluded that it would collaborate with INL in developing energy-related technologies by providing direct funding to selected projects.

13-D has committed approximately $\$ 28 \mathrm{M}$ to fund the development of an improved pre-treatment process used in the bioconversion of biomass feedstock into biofuels. Xtreme Biochemicals, Inc. (XB) was established in 2007 by 13-D to support the funding and development of the pre-treatment process and because of the favorable research results and ever-changing marketplace; XB has recently committed additional funding to expedite the research and scale-up of the pre-treatment process. The commercial impact of this technology will significantly reduce the cost of production of biofuels and result in wider adoption of biofuels.

\subsection{INL Licenses Power-Generating Batteries to M2E}

Capturing energy from motion has long been a dream of inventors, but now it is a reality. INL inventors working with licensee M2E Power, Inc. have succeeded in converting the power of motion into electrical generation and battery charging. The technology they developed is a motion-to-energy power generation system or M2E. These systems are not only commercially viable, they have created buzz among mobile device technophiles, green energy advocates, and military developers.

This sophisticated technology uses an innovative, optimized micro-generator with power management circuitry that kinetically charges mobile batteries from natural motion, such as walking. This breakthrough technology eliminates the need for recharging-effectively taking mobile devices off the electrical grid. This changes the very nature of mobile power. No longer will people need to plug in to get the power needed for smart phones, digital cameras, gaming devices, or mobile audio players. 
The M2E solution uses lightweight, self-charging power units that convert kinetic energy from walking or vehicular motion into electricity. It uses an efficient micro-generator small enough to fit into D, AA, AAA, and cell phone batteries. It can even be scaled to microchip-embedded power systems.

To date, 28 new jobs have been created by M2E Power.

\begin{tabular}{|c|c|}
\hline Licensee & Technology \\
\hline PACECO Corporation & $\begin{array}{l}\text { Apparatus and Method for Inspecting a sealed } \\
\text { Container }\end{array}$ \\
\hline Automation Standards Compliance Institute & $\begin{array}{l}\text { Control System Cyber Security Self-Assessment } \\
\text { Tool }\left(\mathrm{CS}^{2} \mathrm{SAT}\right)\end{array}$ \\
\hline Loft Perch, Inc. & $\begin{array}{l}\text { Control System Cyber Security Self-Assessment } \\
\text { Tool }\left(\mathrm{CS}^{2} \mathrm{SAT}\right)\end{array}$ \\
\hline Xtreme Biochemicals & $\begin{array}{l}\text { Enzyme and Methodology for the Treatment of a } \\
\text { Biomass }\end{array}$ \\
\hline NuScale Power, Inc. & RELAP IRUG \\
\hline BioFuelBox Corporation & $\begin{array}{l}\text { A Process for the Reaction of Glycerides \& Fatty } \\
\text { Acids in a Critical Fluid Medium }\end{array}$ \\
\hline Wyoming Business Council & Wood, Gribik, Boardman Software Model \\
\hline Water Environment Research Foundation & $\begin{array}{l}\text { Control System Cyber Security Self-Assessment } \\
\text { Tool }\left(\mathrm{CS}^{2} \mathrm{SAT}\right)\end{array}$ \\
\hline ESKOM Holdings Limited & RELAP5-3D v2.4 and IRUG \\
\hline Premier Technology & $\begin{array}{l}\text { Coated Armor Systems \& Process for Making the } \\
\text { Same }\end{array}$ \\
\hline AREVA NP Inc. - VA & RELAP5-3D v2.4 \\
\hline M2E Power, Inc. & Self-Charging Battery \\
\hline Xebec Adsorption & Vectored Natural Gas from a Pipeline \\
\hline BKS Energy & $\begin{array}{l}\text { Application to Process Vectored Natural Gas from } \\
\text { a Pipeline }\end{array}$ \\
\hline RFinity & Wireless Sentinel \\
\hline
\end{tabular}




\section{LICENSE OPTION AGREEMENTS}

Seven new license option agreements were executed during FY 2008. Selected licenses are featured below. A list of the remaining new license option agreements are found thereafter.

\subsection{INL Signs Multi-Million Dollar License Option Agreement and CRADA with Precision Nanoparticles, Inc.}

Precision Nanoparticles, Inc., a Washington-based company, recently signed a multi-million dollar CRADA and a $\$ 100,000 /$ year fee bearing license option agreement with INL. The focus of the CRADA project is to explore the development of photovoltaic and sensor devices based on new nanoparticle semiconductor materials. The licensed intellectual property is based on a new low cost method to produce high quality nanoparticles and highly efficient photovoltaic devices resulted from combining Idaho National Laboratory's supercritical fluid chemistry research expertise and Idaho State University's expertise in working with single source precursors. The $\$ 3.1 \mathrm{M}$ project will be led by Dr. Robert Fox (INL) and Dr. Rene Rodriguez (ISU). INL and ISU will both receive approximately $\$ 1.3 \mathrm{M}$ to fund their portion of the work under the CRADA. If commercialization is successful, photovoltaic devices that are inexpensive and have efficiency of $60 \%$ will be available to the American public.

\subsection{INL Signs License Option Agreement with Northstar Medical Radioisotopes, LLC}

Technetium (Tc)-99m is an important life-saving isotope used in nuclear medical imaging procedures. Despite the great demand for Tc-99m, a reliable source for the precursor (Mo-99) does not exist and results in shortages and high costs of Tc-99m. INL inventors developed a novel method of producing Mo99 that greatly reduces the cost of producing Tc-99. Northstar Medical Radioisotopes has licensed the technology for commercialization. If successful, this life-saving procedure will be more available at reduced costs to American citizens.

\begin{tabular}{|l|l|}
\hline \multicolumn{1}{|c|}{ Licensee } & \multicolumn{1}{c|}{ Technology } \\
\hline Xtreme Biochemicals & $\begin{array}{l}\text { Application of Alicyclobacillus to Biomass } \\
\text { Processing }\end{array}$ \\
\hline Xebec Adsorption (2) & Vectored Natural Gas, Non-vectored Gas \\
\hline BKS Energy & Compact Natural Gas Liquefier Process \\
\hline Priority 5 Holdings & Critical Infrastructure Modeling System (CIMS) \\
\hline
\end{tabular}




\section{COOPERATIVE RESEARCH AND DEVELOPMENT AGREEMENTS}

INL has distinguished itself among DOE laboratories with its record of aggressively securing leverage for federal funds in its Cooperative Research and Development Agreement (CRADA) relationships. During FY 2008, INL consummated 15 new CRADA relationships with various parties and 34 modifications to existing CRADAs with total CRADA value approaching \$57M. This amount includes roughly $\$ 32 \mathrm{M}$ of funds-in, $\$ 14 \mathrm{M}$ of in-kind contributions from partners, and approximately $\$ 10 \mathrm{M}$ in government contributions. A CRADA may be as short as a period of months or may extend several years depending on the objectives of the collaboration. The number of transactions and the corresponding resource commitments vary considerably from year to year based on the technologies available at INL, the readiness of participants to invest in collaborations, and INL's ability to identify the right partners and negotiate satisfactory business relationships.

Selected CRADAs are featured below. A list of the remaining CRADAs is found thereafter.

\subsection{INL Partners With Oshkosh Defense to Develop Next-Generation Vehicle Armor}

INL and Oshkosh Defense, a division of Oshkosh Corporation, are collaborating under a CRADA to develop improved armor systems for military vehicles that will save the lives of U.S. soldiers.

Under the CRADA, INL armor scientists and engineers will work with the Oshkosh Armor and Survivability group to improve the armor solutions for Oshkosh's family of defense vehicles. The goal is to provide armor systems with decreased weight and better protection for vehicles facing the threats of improvised explosive devices (IEDs) and explosively formed penetrators (EFPs).

INL has been involved in the development and production of heavy armor for more than two decades. Today, INL's armor-development efforts, under an internally funded and topologically controlled lightweight armor program and direct access to testing ranges, provide basis for rapid materials armor selection, fabricating, and test validation. The laboratory's philosophy is to consistently achieve highperformance, armor-manufacturing solutions, and innovative manufacturing processes that provide affordable products to military, law enforcement, and homeland security personnel. Due in large part to INL's Survivability Program, organizations are able to work with INL armor scientists and engineers in such a way that allows them to rapidly develop and test technology prototypes.

Oshkosh Defense leads the way in military trucks and armored wheeled vehicles. Since 1917, Oshkosh has continuously developed new products and technologies that make military jobs easier, safer, and more efficient. Oshkosh Defense's comprehensive product lines are recognized for superior performance and reliability, particularly in off-road environments.

"INL will work with Oshkosh, a leader in heavy-duty vehicles, to design armor solutions to protect against IEDs and EFPs in theater threats," explained Lisa Nate, INL's Technology Transfer and Commercialization associate who is managing the CRADA. "This collaboration is a great example of 
transferring INL research and development expertise to private industry, which will ultimately benefit the public and INL."

The CRADA tasks will focus on armor modeling, design, and simulation; test-panel validation; initial prototype hardware fabrication; and preliminary recommendations for moving to manufacturing and armor assembly.

"This is a unique opportunity for both Oshkosh and INL to advance armor solutions and improve vehicles for soldiers in the field," said John Stoddart, Oshkosh Corporation Executive Vice President and Defense Division President. "Oshkosh is committed to providing the strongest and most durable vehicles to our military partners, and the INL is helping us accomplish that."

\subsection{INL Signs Multi-Million Dollar CRADA with Battelle Memorial Institute and Other Federal Laboratories}

During FY 2008, INL entered into a multi-million dollar cooperative research and development agreement (CRADA) with Battelle Memorial Institute, Brookhaven National Laboratory, Pacific Northwest National Laboratory, and UT-Battelle, LLC, operator of Oakridge National Laboratory. The CRADA partners have recognized the need to work together to develop a screening system that can identify potential nuclear dirty bombs and other security threats to ensure the safety of American citizens. The focus of the CRADA research project is to further develop INL's Air Cargo technology, which will consist of the development of additional and more detailed technical and operational requirements, final design, final assembly, and integration and testing of the integrated screening system. The total cost is estimated to be around $\$ 41 \mathrm{M}, \$ 4 \mathrm{M}$ of which will come from funds-in contributions.

\subsection{INL Signs Multi-Million Dollar CRADA with BKS Energy, LLC}

In FY 2008, BKS Energy, LLC, a California-based company, signed two CRADAs one of which was a multi-million dollar CRADA. While most projects focus on ways to sequester $\mathrm{CO}_{2}$, INL and BKS Energy are working to take advantage of the greenhouse gas to produce a fuel cycle that results in a netzero $\mathrm{CO}_{2}$ production. The CRADA projects will focus on the development of synthesis gas catalysts for hydrogenation of $\mathrm{CO}$ and $\mathrm{CO}_{2}$ gas streams. The $\$ 5.6 \mathrm{M}$ funds-in project will be led by Dr. Daniel Ginosar and assisted by Drs. Lucia Petkovic and Harry Rollins.

\begin{tabular}{|l|l|}
\hline \multicolumn{1}{|c|}{ CRADA Partner } & \multicolumn{1}{c|}{ Technology } \\
\hline Vermeer Manufacturing Company & $\begin{array}{l}\text { Performance and Efficiency of Biomass } \\
\text { Densification Equipment }\end{array}$ \\
\hline QualTech Systems & Smart Battery Status Monitor \\
\hline $\begin{array}{l}\text { Central Research Institute of Electric Power } \\
\text { Industry }\end{array}$ & $\begin{array}{l}\text { Development of Metal Fuel Fast Reactor Cycle } \\
\text { Technologies }\end{array}$ \\
\hline $\begin{array}{l}\text { Argonne National Laboratory; Kern River Gas } \\
\text { Transmission Company }\end{array}$ & Pipeline Security Vulnerability Assessment \\
\hline TerraEchos, Inc. & Blue Rose Test And Evaluation Center \\
\hline
\end{tabular}




\begin{tabular}{|l|l|}
\hline \multicolumn{1}{|c|}{ CRADA Partner } & \multicolumn{1}{c|}{ Technology } \\
\hline Compact Membrane Systems, Inc. & $\begin{array}{l}\text { Exploration of Blending and Formation of } \\
\text { Interpenetrating Networks in Unique Polymers }\end{array}$ \\
\hline Precision Nanoparticles, Inc. & $\begin{array}{l}\text { Improved Fabrication Methods and materials for } \\
\text { Advanced Photovoltaic and Semiconductor } \\
\text { Device }\end{array}$ \\
\hline Saint Gobain Ceramics \& Plastics & Solid Oxide Cell Systems Evaluation \\
\hline Wyoming Business Council & Aspen Code Development Collaboration \\
\hline Premier Technology, Inc. & Elements for Protective Solutions \\
\hline Battelle Memorial Institute & Polymers for CO2 Separation Processes \\
\hline Oshkosh & Full Spectrum Armor for Support Vehicles \\
\hline BKS Energy (2) & $\begin{array}{l}\text { Hydrogenation of Clean Carbon Monoxide (CO) } \\
\text { and Carbon Dioxide (CO2) Gas Streams to } \\
\text { Higher Molecular Weight Alcohols \& CO2 } \\
\text { Capture }\end{array}$ \\
\hline
\end{tabular}




\section{WORK FOR OTHERS}

The INL's Work for Others program had another exceptional year in FY 2008. DOEID approved 58 new WFO projects and the program has reached more than $\$ 300 \mathrm{M}$ in funding. In addition, on November 1, 2007, the WFO office received DOE-ID approval to start using a new WFO vehicle called a "Technical Services Agreement" (TSA). This is a streamlined process/agreement for low dollar, low risk WFO projects. INL executed 18 TSA's during the fiscal year.

WFO Manager, Al Hoiland, states, "I am also pleased to report that we are on schedule to kick off the Work for Others Automated

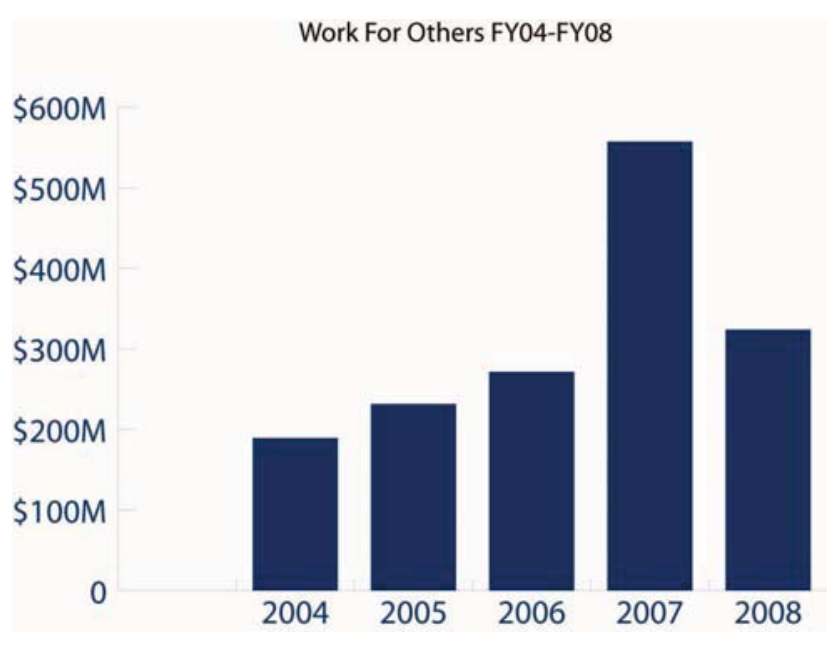
Processing System (WPS) by October 31, 2008. This new tool will speed up the approval of new and modified WFO projects."

Some of INL's more significant WFO projects include work with the U.S. Army to develop and demonstrate new countermine detection technology for robotics platforms, as well as laboratory efforts to improve the security of high value assets for the Defense Threat Reduction Agency (DTRA).

INL is also engaged with numerous nonfederal sponsors via the WFO program, including several foreign governments such as Japanese Atomic Energy Agency for a fatigue analysis of EBR-II; Korea Atomic Energy Research Institute related to High Temperature Steam Electrolysis; and the Alberta Research Council related to nuclear energy options. INL has also worked with small businesses such as Sagebrush Capital in Jackson, WY, related to Wind Power; New Forrest Strategies in Modesto, CA, related to investigating supercritical fluid treatment processes on samples of Radiata Pine; and NuScale Power in Corvallis, OR, to assist with accident analysis related to nuclear safety. A few of the large businesses INL has worked with include AREVA NP, based locally in Idaho Falls, to explore ways in which heat from the nuclear reactor or its power conversion cycle can be used in the coal-to-liquids process; Waste Control Specialists in Dallas, TX, for Vadose Zone monitoring; and Shell Global Solutions, based in Houston, TX, related to Biomass Feedstock studies.

A list of the new WFO and TSA projects approved and funded during 2008 are found below.

\begin{tabular}{|l|l|}
\hline \multicolumn{1}{|c|}{ Sponsor } & \multicolumn{1}{c|}{ Project Title } \\
\hline North Wind Environmental, Inc. & Harford 118-K Measurements \\
\hline AREVA NP & AREVA Lignite LWR CTL \\
\hline William Lettis \& Associates, Inc. & Ground Motion Panel Review \\
\hline Office of Naval Research & $\begin{array}{l}\text { Production of Synthetic Military Fuel Modeling } \\
\text { Support }\end{array}$ \\
\hline
\end{tabular}




\begin{tabular}{|c|c|}
\hline Sponsor & Project Title \\
\hline University of Utah & $\begin{array}{l}\text { Transport and Deposition of Mercury to Southern } \\
\text { Idaho }\end{array}$ \\
\hline Defense Threat Reduction Agency (DTRA) (3) & $\begin{array}{l}\text { Weapon Vault Storage, Radiography and Imaging } \\
\text { System Support, Smart Threads Integrated } \\
\text { Radiation Sensor Joint Concept Technology } \\
\text { Demonstration (STIRS JCTD) Support }\end{array}$ \\
\hline Sagebrush Capital, LLC & Sagebrush Capital Wind Power Support \\
\hline Japanese Atomic Energy Agency & $\begin{array}{l}\text { Japanese Atomic Energy Agency (JAEA) Fatigue } \\
\text { Analysis of EBR-II }\end{array}$ \\
\hline $\begin{array}{l}\text { U.S. Army Night Vision \& Electronic Sensors } \\
\text { Directorate - NVESD }\end{array}$ & $\begin{array}{l}\text { Countermine Mobility, Marking, Autonomy \& } \\
\text { Detection (CMMAD) }\end{array}$ \\
\hline Battelle Memorial Institute (6) & $\begin{array}{l}\text { Zero Emissions Hydrocarbon Support, Project } \\
\text { Planning/Project Management Assistance to BMI } \\
\text { for Renewable Energy Laboratory - } \\
\text { Kaula Lumpur, Bio-Energy Support to Battelle } \\
\text { Memorial Institute - TSA, Elk River Spent } \\
\text { Nuclear Fuel Assessment, TSA PETRONAS } \\
\text { Feedstock Assembly Workshop }\end{array}$ \\
\hline Rivada Networks, LLC & Interoperable Communications Systems \\
\hline The NanoSteel Company, Inc. & $\begin{array}{l}\text { Spray Forming of Iron Based Glass Forming } \\
\text { Alloys }\end{array}$ \\
\hline New Forrest Strategies, LLC & New Forrest Strategies \\
\hline Pacific Northwest Economic Region (PNWER) & $\begin{array}{l}\text { Analysis of Regional Energy Needs \& } \\
\text { Vulnerabilities (PNWER) }\end{array}$ \\
\hline Waste Control Specialists, LLC & WCS Vadose Zone Monitoring \\
\hline Synthesis Energy Systems & $\begin{array}{l}\text { Simulation of Gasification and Methanol } \\
\text { Synthesis - TSA }\end{array}$ \\
\hline $\begin{array}{l}\text { Toyota Motor Engineering \& Manufacturing } \\
\text { North America Inc. (TEMA) }\end{array}$ & Toyota Polymer Project \\
\hline $\begin{array}{l}\text { Utah Associated Municipal Power Systems } \\
\text { (UAMPS) }\end{array}$ & UAMPS Wind Power Support -TSA \\
\hline PJM Interconnection, LLC & $\begin{array}{l}\text { Presentation: Cyber Security for Operations - } \\
\text { TSA }\end{array}$ \\
\hline
\end{tabular}




\begin{tabular}{|c|c|}
\hline Sponsor & Project Title \\
\hline Naval Sea Systems Command & $\begin{array}{l}\text { Naval Sea Systems Command (NSSC) Request of } \\
\text { INL Management of Offsite Recovery Program } \\
\text { (OPR) Disposal of } 12 \text { Navy RTGs }\end{array}$ \\
\hline GSE Power Systems, Inc. & GSE RELAP5-RT Technical Support \\
\hline NuScale Power, Inc. & NuScale Power Accident Analysis Support \\
\hline Raytheon & WTB - Raytheon May Test \\
\hline U.S. Environmental Protection Agency (EPA) & $\begin{array}{l}\text { EPA-AST Web-Based Vehicle Management } \\
\text { Information System Support \& Enhancement }\end{array}$ \\
\hline $\begin{array}{l}\text { Defense Advanced Research Project Agency } \\
\text { (DARPA) }\end{array}$ & Hyper-adsorbent Validation Support \\
\hline Boron Products, LLC & Boron Products Waste Form Test Program \\
\hline Roll-Royce, LLC & RELAP5 Training for Rolls Royce \\
\hline Edenspace Systems Corporation (SB) & $\begin{array}{l}\text { Edenspace - Model Economic Impact of Corn on } \\
\text { Storage - TSA }\end{array}$ \\
\hline Quantum Magnetics, Inc & Body Cavity Screening Device \\
\hline Florida Power and Light & $\begin{array}{l}\text { Cyber Security Assessment of AMI/AMR } \\
\text { Technology }\end{array}$ \\
\hline Israel Electric Corporation & $\begin{array}{l}\text { Israel Electric Corporation Vulnerability } \\
\text { Assessment }\end{array}$ \\
\hline Portage Environmental & $\begin{array}{l}\text { H-Area Tank Farm Performance Assessment, } \\
\text { SRNL }\end{array}$ \\
\hline Shell Oil Company & $\begin{array}{l}\text { Carbon Dioxide Mineralization Potential of Host } \\
\text { Rocks in Deep Saline Aquifers }\end{array}$ \\
\hline Shell Global Solutions (US) Inc. & Biomass Feedstock State of Technology Report \\
\hline BKS Energy LLC & $\begin{array}{l}\text { Implementation of Compact LNG System on } \\
\text { Natural Gas Pipelines }\end{array}$ \\
\hline NucSafe, Inc. & $\begin{array}{l}\text { Testing of Radiation Measurement \& Detection } \\
\text { Instrumentation }\end{array}$ \\
\hline
\end{tabular}




\begin{tabular}{|c|c|}
\hline Sponsor & Project Title \\
\hline $\begin{array}{l}\text { U.S. Army Engineer Research and Development } \\
\text { Center (3) }\end{array}$ & $\begin{array}{l}\text { Current State of Practice of Geophysical } \\
\text { Techniques for Detecting Seepage and Internal } \\
\text { Erosion in Embankment Dams Resistivity } \\
\text { Testing, Monitoring Chronic Surface Seepage, } \\
\text { Buck Chute }\end{array}$ \\
\hline Bureau of Reclamation (Denver) (2) & $\begin{array}{l}\text { Electromagnetic Geophysical Surveys for Yuma } \\
\text { Area Levee Certification Project }\end{array}$ \\
\hline Performance Improvement International & $\begin{array}{l}\text { PII Material Characterization and Failure } \\
\text { Analysis }\end{array}$ \\
\hline AREVA Federal Services, LLC - WA & SAPHIRE Training for AREVA Federal Services \\
\hline National Communications Systems (NCS) & $\begin{array}{l}\text { Communications Dependency on Electric Power } \\
\text { Working Group Support }\end{array}$ \\
\hline Alberta Research Council & $\begin{array}{l}\text { Nuclear Energy Options Report for the Alberta } \\
\text { Research Council (ARC) }\end{array}$ \\
\hline $\begin{array}{l}\text { United States Agency for International } \\
\text { Development (USAID) }\end{array}$ & $\begin{array}{l}\text { USAID Web-based Motor Vehicle Management } \\
\text { Information System }\end{array}$ \\
\hline $\begin{array}{l}\text { National Aeronautics and Space Administration - } \\
\text { Planetary Science }\end{array}$ & Exploring Bio/Organic Signatures in Geomatrices \\
\hline Information Systems Laboratories (ISL) (2) & $\begin{array}{l}\text { Risk Informed Decision Making (RIDM), } \\
\text { Accident Precursor Analysis for ISL }\end{array}$ \\
\hline Korea Atomic Energy Research Institute & $\begin{array}{l}\text { Training KEPRI Engineers on the HTSE System } \\
\text { Analysis }\end{array}$ \\
\hline Luna Innovations Inc. & Luna Irradiation Test Feasibility and Planning \\
\hline
\end{tabular}




\section{TECHNICAL ASSISTANCE}

The INL Technical Assistance Program provides INL technical expertise to address a variety of needs of state and local governments and regional small businesses each year. The requesting organization can receive up to 40 hours of laboratory personnel time at no cost to them to address technical needs that cannot readily be met by commercially available resources in the region. The program is funded with internal funds.

In FY 2008, INL completed 21 technical assistance projects. With various projects going on simultaneously, laboratory employees who participate in the Technical Assistance Program often are asked to work with several customers at the same time. Some of their stories are featured below and reflect the unique capabilities INL has to offer.

\section{Technical Assistance FY04-FY08}

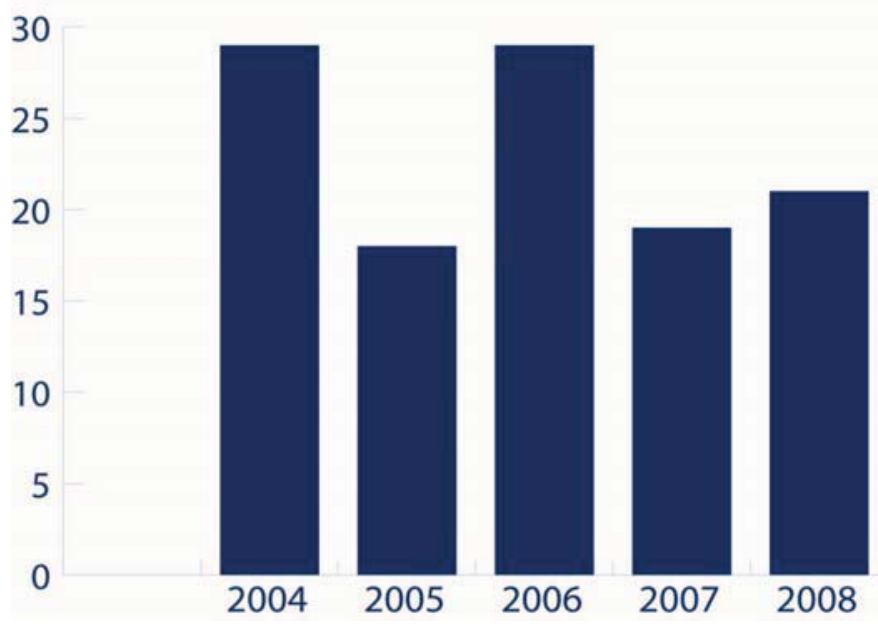

\subsection{Unique Glasswork Contributes to INL and Community}

Russel Lewis is the only Scientific Glass-blower at INL. Lewis does not only perform modifications to existing lab ware, fabricate new apparatus from scratch, and assist researchers in designing lab ware for unique design and capabilities, but he has also supported the INL's Technical Assistance program for four years.

During FY 2008, Lewis contributed to the success of two Technical Assistance projects. Lewis assisted the University of Idaho (U of I) by fabricating a furnace tube made of quartz glass with an internal assembly to attach media discs that the U of I flows gas through. He constructed the assembly with ground joints to aid in assembly and disassembly for media change out and gas test ports to monitor flow and pressure.

Lewis also repaired a boiler assembly sent in from Enterprise High School in Enterprise, OR. Lewis performed the repair by cutting the bottom of the boiler off and fabricating a new bottom.

Technical Assistance projects that Lewis performed in the past include modifying a 32" diameter condenser bowl that is no longer produced to allow installation of a drain fitting; fabricating quartz reaction vessels for Brigham Young University-Idaho (BYU-ID), constructing vacuum lines and extraction vials for ISU, and the fabrication of a quartz furnace tube for the $\mathrm{U}$ of $\mathrm{I}$, of which Lewis made various retrofits to the assembly to accommodate different test media.

Lewis states that the Technical Assistance program "is a great resource for the researcher who doesn't have access to some of the unique capabilities that INL has to offer." Among the INL's distinctive capabilities are the unique abilities of Russel Lewis. 


\subsection{INL Assists Community Efforts to Preventing Domestic Violence}

Bruises, scars, tears, and fears may be the only things that victims of domestic violence recognize as their companions. Victims may feel alone and assume that there is no possibility to escape from their victimizer. However, they are not alone and they can escape. Among several places where victims of domestic violence can find support is the Domestic Violence Intervention Center (DVIC) in Idaho Falls, Idaho.

DVIC is a non-profit organization that provides services to families and victims of domestic violence and sexual assault. DVIC was interested in turning a 1940 building, once used as a church, into a family justice center. DVIC requested technical assistance from INL to perform a structural evaluation.

A walk-through inspection of the building was performed by INL engineers Stephanie L. Austad and Brent G. Harris. The inspection helped determine what damage the building had and if it would be feasible to renovate.

The structural evaluation helped DVIC analyze their options. Teena McBride, DVIC Executive Director, declared that the INL's Technical Assistance program helped DVIC obtain expert advice that they would not have been able to obtain otherwise. DVIC was able to make an informed decision that would help maintain the health and safety of their clients and employees.

\subsection{Preserving History: One Roof at a Time}

Located near the spectacular Snake River falls is the heart of Idaho Falls, Idaho - Historic Downtown. Idaho Falls' downtown comprises over a dozen preserved buildings listed in the National Register of Historic Places. Preserving these buildings is one of the goals of the Idaho Falls Downtown Development Corporation, which sought out assistance from INL's Technical Assistance Program.

INL engineers Stephanie Austad, Tracy Langenwalter, and Pat Bragassa performed inspections of the three buildings on Constitution Way in Historic Downtown. The Idaho Falls Downtown Development Corporation wanted to preserve the buildings instead of demolishing them and their rich historical content. INL engineers provided different alternatives to demolishment of the buildings. Among these options were reuse through restoration and reuse through rehabilitation. Recommendations offered by INL engineers included roof repair, roofing systems replacement, and using materials similar to the ones originally used.

Through this Technical Assistance project, INL helped recommend ways to preserve the historical legacy of Idaho Falls. The assistance received through the Technical Assistance program also reaches beyond the Idaho Falls community to Custer County, where INL civil/structural engineers Stephanie Austad and Pat Bragassa performed a field evaluation of the Custer County Courthouse as well.

Engineering assistance had been requested by Custer County's Clerk, Barbara Breedlove, in order to evaluate the courthouse's roof. INL engineers offered their recommendations after evaluating the courthouse and proposed a roof replacement and offered corrections to code violations that were discovered during the evaluation.

Langenwalter stated, "We all enjoy working with area city and county officials who need engineering support. The work is enjoyable and rewarding. Those we support are always very grateful."

Also during FY 2008, three separate projects requests were received in addition to the project mentioned above. Each project will assist with other Idaho Falls Downtown Development Corp projects. 
Additional projects completed in FY 2008 are as follows:

- Bonneville Restroom Construction/Extension 4-H/Blackfoot Fairgrounds - The Bonneville County Extension/Fair Board is in pursuit of adding restroom facilities to the Jack Hamilton Building.

- Land View Fertilizer - Land View Fertilizer sought the expertise of INL to establish the most environmentally friendly and economic use of piles of ash and beet lime.

- Tetra Tech - Tajma Vaughns - Rachal requested technical assistance in identifying economically effective remediation methods for sites located in the state of California.

- BLM - BLM Wildlife biologist, Theresa Mathis, requested the assistance of INL biologist, Dr. Angelica Stormberg, to assist in wildlife monitoring projects.

- Idaho City - INL engineers, Neal Yancey and Clark Scott, assisted the Idaho City community by providing a review of the city's waste water treatment facility.

- City of Crough - During 2008, the City of Crouch was told that their system would fail in 18 months. Dawn Smith, from the Crouch City Council, requested a study be to determine if the local sewer plant could process the sewage using a new line.

- Idaho Falls Babe Ruth and Cal Ripken Baseball, Inc. - Scott Birkinbine, President of the Idaho Falls Babe Ruth and Cal Ripken Baseball, Inc., requested INL's help with submitting a grant needed to improve the conditions of several baseball fields and other facilities.

- Idaho Falls School District 91 - INL's Ernest L. Fossum served on a selection panel along with legal and technical members of IFSD \#91 to review two Energy Performance and Design-Build contracting proposals for a large upgrade project.

- TerraGraphics Environmental Engineering Inc. - TerraGraphics Environmental Engineering Inc. requested assistance in looking for innovated approaches towards remediation because the basalt geology makes it difficult to understand the groundwater in the area.

- Idaho Falls Power - James R. Davidson assisted Idaho Falls Power personnel with the understanding of the North American Electric Reliability Corporation's (NERC)'s Critical Infrastructure Protection (CIP) standards.

- City of Idaho Falls - The City of Idaho Falls requested assistance in evaluating a 1930's-era building that could potentially serve as a fire department station.

- Energy Systems Technology and Education Center (ESTEC) - Richard Holman, ISU's Associate Director for Industrial Research Programs, requested technical assistance from INL to examine the new ESTEC building to recommend energy efficient and green building technologies to be incorporated into the renovation.

- Taylor Crossing Event - INL employee Edward Anderson provided bleachers for Taylor Crossings' Summer Days event.

- CEO Autonomous Solutions, Inc. -Mel Torrie from CEO Autonomous Solutions, Inc. requested a trailer equipped for Command and Control on Unmanned Systems. Derek C. Wadsworth and Mark McKay provided assistance by transporting an INL Unmanned Vehicle Control Trailer to Victorville, California and offering their robotics engineering expertise. 


\section{INL ECONOMIC DEVELOPMENT 2008 PROGRAM HIGHLIGHTS}

\subsection{Overview}

INL's Technology Partnerships-Economic Development organization aggressively implements, directs, and collaborates with organizations across the state to foster technology-based economic development. By leveraging INL staff and management expertise in marketing, business case development, and assessment, training, event orchestration, and small business outreach, the Laboratory in 2008 assisted Idaho in accelerating its economic development and diversification goals.

\subsection{Economic Development Asset Enhancement}

INL has invested more than $\$ 200,000$, plus in-kind services, in technology-based economic development programs across Idaho for FY 2008. Together with Idaho TechConnect, Idaho Economic Development Association, Idaho Department of Commerce, and other public and private organizations across the state, INL organized TechLaunch, an educational event that teaches entrepreneurs how to pitch their ideas to investors. Entrepreneurs from across Idaho presented their business plans to a panel of judges representing various aspects of the financing food chain, including venture capital, angels investors, and commercial bankers. Over the course of five years, 37 companies have participated, raising a total of more than $\$ 24$ million in R\&D and investment funds. This year, the event featured the winners of Idaho's university business plan competitions.

INL also has taken a lead role in the Idaho Entrepreneurial Project to grow Idaho's entrepreneurial economy by identifying resources and coordinating efforts. Essentially, the project funnels individuals through curriculum at every grade level, identifying internship opportunities and equipping students with skills to compete in today's economy. The end result will be an entrepreneurially educated workforce, capable of owning and operating their own businesses or apply their talents to the Laboratory or one of Idaho's existing companies, helping them to grow and expand.

\subsection{INL continues to work with the Eastern Idaho Entrepreneurial Center}

Since 2007, INL Technology Transfer \& Commercialization (TT\&C) office has been working with the Eastern Idaho Entrepreneurial Center, or E Center, located in Rexburg, ID, to give project opportunities to senior-level students attending BYU-Idaho. The E Center works with students and interns to provide entrepreneurs and small businesses with ideas of how to improve their company. INL has been participating by giving students market-assessment or business-plan projects related to INL technologies. The program is expected to expand and it is anticipated Idaho State University (ISU) will participate during spring semester 2009.

\subsection{New venture fund established in Idaho}

A new "seed" venture fund is now available in southeastern Idaho thanks to several regional organizations consisting of Highway 12 Ventures, EPIC Ventures, Battelle Ventures, and a few regional "accredited investors." The main focus of the fund is to invest in start-up companies located in southeast Idaho as well as to look at technologies that may have the potential to be spun out from INL, and to establish the new company in southeast Idaho.

About eight months ago, Tom Harrison, director of INL's TT\&C office, and Bob Pothier, an EPIC Ventures managing partner, began discussing the possibility of establishing a "seed" venture fund in Idaho. In a relatively short amount of time, the $\$ 5$ million-plus-venture fund was established. During FY 
2008, eight different investment opportunities were presented and analyzed, of which three have been funded.

The "seed" venture fund is managed by the board of directors of the Eastern Idaho Entrepreneurial Center of Rexburg, and investment opportunities are reviewed on a monthly basis. The board of directors consists of:

- Todd Stevens, EPIC Ventures Fund managing director

- Corey Smith, CEO, Eastgate Drug Inc.

- Fenton Broadhead, college dean, BYU-Idaho

- Heber Andrus, president, Doug Andrus Distributing

- Ted Hendricks, Economic \& Community Development manager, The Development Company

- Richard Smith, private entrepreneur

In addition, EPIC Ventures closed another venture fund of \$150 million in FY 2008 and will focus on investing in Idaho opportunities. With EPIC's Bob Pothier physically located in southeastern Idaho, EPIC Ventures is able to work closely with INL and other potential partners in using the fund to further the overall economic development in the state.

\section{Other Successes}

\subsection{INL's Innovation Development Fund Proves Successful}

The TT\&C Innovation Development Fund (IDF) is a mechanism to fund the advancement of technologies and intellectual property developed by INL employees. The IDF is funded by fees and royalties from intellectual property licenses or other income earned or retained by the contractor from the performance of authorized technology transfer activities. The primary goal of the fund is to enhance the likelihood of transferring laboratory developed technologies to nonfederal parties in accordance with the principles and purposes of federal technology transfer legislation.

In its short history, INL's IDF has been very successful in its objective to enhance the likelihood of transferring laboratory developed technologies to nonfederal parties to meet the purposes of technology transfer legislation. With about $\$ 300 \mathrm{~K}$ of funded projects and eight completed projects to date, the following results have been achieved:

- Funding was provided to demonstrate an ultrahydrophic surface technology which resulted in a \$1.7M partnership with GE;

- Funding was provided to demonstrate an oil shale mercury sorption technology which resulted in a $\$ 500 \mathrm{~K}$ follow on demonstration funded by a licensee;

- Funding was provided to prototyped a photovoltaic technology resulting in a negotiated $\$ 3 \mathrm{M}$ CRADA and license agreement;

- Funding was provided to prototype a wireless monitoring device resulting in license agreement negotiations resulting a license agreement and a start-up company, and

- Funding was provided to perform bench scale demonstration of a catalyst to convert carbon oxides to ethanol and butanol, which lead to a \$5M CRADA. 


\subsection{INL researchers win 2008 R\&D 100 award}

Nine researchers at Idaho National Laboratory won an award in the latest $R \& D$ Magazine world-wide competition for the top 100 technologies during 2008.

INL researchers have developed Antibody Profiling Identification (AbP ID), a rapid, inexpensive method to identify forensic evidence based on unique individual auto-antibody patterns. AbP ID incorporates a testing system and innovative pattern recognition software to expedite identifications. Industry experts see AbP ID as an important complementary tool to DNA processing.

"After a decade of research and laboratory work, our science soon will begin contributing to forensic investigations, medicine, and potentially many other areas," INL research team leader Vicki Thompson said. "We are honored with this award and personally rewarded with satisfaction from our contribution."

"This is yet the latest example of how the Department of Energy and our national laboratories are continuing to demonstrate world-class leadership in innovation as we enhance our energy security, national security and economic competiveness," Energy Secretary Samuel W. Bodman said. "On behalf of the Department, I would like to congratulate all of our employees who have earned R\&D 100 awards and in particular this year's winners."

Identity Sciences, LLC, of Georgia, has licensed the technology and is preparing products for market. "We believe that Antibody Profiling Identification will complement DNA testing and aid forensic experts in solving cases more quickly," Identity Sciences Chief Executive Officer Gene Venesky said.

\subsection{INL Recognized with Three FLC Far West Region Awards}

The Federal Laboratory Consortium Far West Region recognized INL with three awards during FY 2008. The Motion to Energy (M2E) technology was recognized with the Outstanding Technology Development award, which is given to a laboratory and staff for a promising technology development which solves a problem, satisfies markets and/or consumers, and/or creates patents and awards. A second award recognized an INL outstanding partnership: Identity Sciences, LLC. This award category recognizes any entity that has been germane in a successful partnership working with federal laboratories and technology transfer in the region. In addition to these awards, INL was also recognized with an Outstanding Commercialization Success Award, which identifies a technology transfer success story that has resulted in the commercialization of a laboratory technology. This award acknowledged the commercialization success of INL's WyINL Code to the Wyoming Business Council.

\subsection{Laboratory Technologies Recognized at Annual Event}

An Idaho National Laboratory technology won top honors and a second was a finalist at the third annual Stoel Rives Idaho Innovations Awards. INL's forensic technology Antibody Profiling Identification captured the category for Innovation of the Year and Commercialized Technology and another INL-developed technology, Motion to Energy Power Generation, earned finalist honors in the same category. Congratulations to both on this achievement.

This year, the competition was sponsored by the Idaho Business Review and supported by accounting firm Cooper Norman. It is the only program that recognizes innovation among all companies in Idaho. Individual innovators also were recognized for the first time this year.

The 2008 Idaho Innovation Awards winners and finalists were:

Innovation of the Year/Commercialized Technology:

Winner: Antibody Profiling Identification (AbP ID) by Idaho National Laboratory 
Finalist: Motion to Energy Power Generation by Idaho National Laboratory and Boise-based research partner M2E Power Inc.

Finalist: M-Vac System by Microbial-Vac Systems Inc. of Jerome.

Innovation of the Year/Early-Stage Technology:

Winner (tie): BookLamp.org by Novel Projects, Inc. of Boise.

Winner (tie): IMS Environmental Probe of Boise State University.

Finalist: Kount E-Commerce Fraud-Control Technology by Kount, Inc. of Boise

Innovative Company of the Year:

Winner: Keynetics, Inc. of Boise

Finalist: Marketron Broadcast Solutions of Hailey

Finalist: Melaleuca of Idaho Falls

Innovator of the Year:

Winner: Timothy Barber, chief scientist at Keynetics Inc. of Boise

Finalist: Bruce J. Bradley, CEO of Microbial-Vac Systems Inc. of Jerome

Finalist: Frank VanderSloot, president and CEO of Melaleuca of Idaho Falls 